\title{
Op koers naar een nieuw tijdperk
}

Het zijn roerige tijden in huisartsenland. In het voorjaar 2015 werd het actiecomité Het Roer Moet Om (HRMO) opgericht als protest tegen de uitbreidende macht van de zorgverzekeraars. Men wenste meer gelijkwaardigheid in de onderhandelingen, minder administratieve lasten en meer vertrouwen in het kwaliteitsbeleid van de beroepsgroep. HRMO kreeg binnen korte tijd grote steun van de achterban en van de minister. Er werd een actieplan geformuleerd, waarna vertegenwoordigers van de huisartsen, zorgverzekeraars, patiëntenorganisaties en de overheid in diverse werkgroepen aan de slag gingen.

\section{A CRISIS IN GENERAL PRACTICE}

De knelpunten die huisartsen in Nederland ervaren, zijn niet uniek. Huisartsen in andere landen kampen met dezelfde problematiek. ${ }^{1}$ De bureaucratie en werkdruk nemen toe en professionals moeten steeds meer externe verantwoording afleggen. Vooral in landen waar contracten met zorgverzekeraars worden gesloten, zoals Duitsland, Zwitserland en de Verenigde Staten, ervaren de artsen hoge administratieve lasten. In het Verenigd Koninkrijk spreekt men vanwege de toenemende werkdruk en regelgeving zelfs van een crisis in general practice. ${ }^{2}$

\section{DE VISIE VAN BERWICK}

Wie anders dan Don Berwick, goeroe van het kwaliteitsdenken, zou zich deze zorgelijke ontwikkelingen moeten aantrekken? In de JAMA beschrijft hij drie tijdperken in de gezondheidszorg waarbij het derde tijdperk een blik vooruit werpt. ${ }^{3}$ De overgang van het tweede naar het derde tijdperk vertoont opvallende overeenkomsten met HRMO in Nederland.

\section{Eerste tijdperk: professionele autonomie}

Het eerste tijdperk grijpt terug op Hippocrates. De autoriteit van de arts werd bekrachtigd door het privilege om zelf te oordelen over de kwaliteit van het werk. De klassieke eed van Hippocrates met het beroepsgeheim als één van de regels, sluit de deur van de spreekkamer voor pottenkijkers. Met de introductie van landelijke registratiesystemen in de vorige eeuw werd echter grote praktijkvariatie zichtbaar die niet kon worden verklaard door verschillen in patiëntenpopulaties. Dit gold ook voor complicaties na ingrepen en voor medische fouten. De kwaliteit en veiligheid van de zorg kwamen in het geding.

\section{Tweede tijdperk: externe verantwoording}

Het marktdenken en registreren van zorgprestaties werden vervolgens ingevoerd om onderscheid te kunnen maken in kwaliteit. De patiëntgegevens werden anoniem en op geaggregeerd niveau verzameld. Artsen en zorginstellingen moesten met de billen bloot. De deur van de spreekkamer ging open. De toenemende druk om verantwoording af te leggen leidde tot onvrede bij de beroepsgroep. Artsen stonden tegenover zorgverzekeraars en overheid in plaats van naast elkaar.

\section{Derde tijdperk: 'the moral era'}

Een gemotiveerde beroepsgroep is van levensbelang voor een toekomstbestendige gezondheidszorg. Berwick beschrijft hiertoe negen gewenste veranderingen [tabel]. De meeste van deze veranderingen hebben een pendant in de HRMO-beweging, wat aantoont dat de problematiek die HRMO beschrijft ook elders de gemoederen bezighoudt.

\section{HET ROER GAAT OM}

Ongeveer een jaar na de oprichting van HRMO werd tijdens de LHV Huisartsbeurs 2016 een tussenrapportage gegeven, met de boodschap dat er 'mooie resultaten zijn geboekt die het werk van huisartsen makkelijker en weer aantrekkelijker maken'. ${ }^{4}$ Het vertrouwen in de koers die is ingezet, is vertaald in Het Roer Gaat Om. ${ }^{5}$ De betrokken partijen blijven actief en gaan door met het realiseren van de gestelde doelen. De zeilen blijven bol staan. Liggen we op koers naar een nieuw tijdperk?

\section{LITERATUUR}

Zie www.henw.org, rubriek Commentaar.

NHG, Richtlijnontwikkeling en Wetenschap, Postbus 3231, 3502 GE Utrecht: dr. J.S. Burgers: huisarts en hoofd afdeling R\&W • Correspondentie: j.burgers@nhg.org • Mogelijke belangenverstrengeling: de auteur was van juli tot begin september 2015 voorzitter van de werkgroep Kwaliteit in het kader van HRMO.

Tabel Negen aanbevelingen voor 'the moral era' en HRMO-koers

\begin{tabular}{ll} 
The moral era & HRMO-koers \\
\hline Verminder verplichte metingen & Reduceer het aantal indicatoren in de huisartsen- en ketenzorg \\
Stop met complexe individuele (financiële) prikkels & Stop met prestatiebeloning van individuele huisartsen \\
Focus op kwaliteit in plaats van opbrengst & Vervang het marktdenken door kwaliteitsdenken \\
Laat het professionele privilege varen & Streef naar professionele verantwoordelijkheid in plaats van professionele autonomie \\
Gebruik kennis over kwaliteitsverbetering & Besteed meer aandacht aan intervisie als onderdeel van de kwaliteitscyclus \\
Streef naar volledige transparantie & Werk mee aan inzicht in kwaliteit van de huisartsenpraktijk \\
Blijf beleefd en beschuldig niet & Blijf constructief en in dialoog met alle partners in de zorg \\
Luister naar patiënten en naasten & Geef exclusieve aandacht aan de patiënt en lever persoonsgerichte zorg \\
Verwerp hebzucht & Streef naar kleinere praktijken en redelijke bekostiging van de huisartsenzorg
\end{tabular}

